\title{
Effect of systemic intravenous infusion of PGF-2 $\alpha$ and 13,14-dihydro-15-keto-PGF-2 $\alpha$ on the release of oxytocin-associated neurophysin from the ovary in the ewe
}

\author{
W. B. Watkins and L. G. Moore* \\ Postgraduate School of Obstetrics and Gynaecology, University of Auckland, \\ National Women's Hospital, Claude Road, Auckland 3, New Zealand
}

\begin{abstract}
Summary. Systemic intravenous infusion of physiological concentrations of PGF-2 $\alpha$ and its major metabolite, 13,14-dihydro-15-keto-PGF-2 $\alpha$ (PGFM) into non-pregnant ewes possessing a corpus luteum induced the release of oxytocin-neurophysin. These results suggest that, during luteolysis, endogenous release of uterine PGF-2 $\alpha$ would be able to stimulate the release of ovarian oxytocin and oxytocin-neurophysin from the ovary.
\end{abstract}

\section{Introduction}

In the non-pregnant ewe, pulsatile release of uterine prostaglandin (PG) F-2 $\alpha$ induces regression of the corpus luteum about 14 days after oestrus (McCracken et al., 1972). Recent evidence indicates that oxytocin may be involved in luteolysis in sheep: immunizing ewes against oxytocin delays luteolysis (Sheldrick et al., 1980; Schams et al., 1982) and exogenous oxytocin stimulates uterine PGF release (Roberts et al., 1975). There is also a temporal relationship between the pulsatile releases of oxytocin-neurophysin, oxytocin and 13,14-dihydro-15-keto-PGF-2 $\alpha$ (PGFM) during luteolysis (Fairclough et al., 1980, Flint \& Sheldrick 1983). It has been suggested that PGF-2 $\alpha$ induces the release of oxytocin and oxytocin-neurophysin during luteolysis (Flint \& Sheldrick, 1982). In support of this it has been shown that large doses of PGF-2 $\alpha$ (R. J. Fairclough, A. J. Peterson, L. G. Moore, \& W. B. Watkins, unpublished) or cloprostenol, a PGF-2 $\alpha$ analogue, are able to stimulate oxytocin and oxytocin-neurophysin release in ewes (Flint \& Sheldrick, 1982; Watkins et al., 1984).

However, in sheep PGF-2 $\alpha$ is nearly completely metabolized by a single passage through the lungs (Piper et al., 1970; Davis et al., 1980). It has therefore been considered unlikely that physiological levels of PGF-2 $\alpha$ could cause oxytocin and oxytocin-neurophysin release by a systemic route (Fairclough et al., 1980), although it is possible that PGF-2 $\alpha$ metabolites could cause oxytocin release (Milvae \& Hansel, 1983) or PGF-2 $\alpha$ may induce oxytocin release by a local route. The aim of the present study was to determine whether systemic infusion of approximately physiological concentrations of PGF-2 $\alpha$ or of the major metabolite 13,14-dihydro-15-keto-PGF-2 $\alpha$ (PGFM), is able to cause the release of oxytocin-neurophysin.

\section{Materials and Methods}

Animals. Romney ewes ( $40-45 \mathrm{~kg}$ body weight) from 2 to 5 years of age were used. Groups of 5 animals were used in each experiment except the Day 18 and Day 21 hysterectomized animals when only 2 ewes were used on each day. The hysterectomies and ovariectomies were performed on the ewes at least 6 months before the experiments were conducted except for the 2 Day-18 and 2 Day-21 ewes in which the operations were carried out on Day 7 of the

*Present address: Wallaceville Animal Research Centre, Upper Hutt, New Zealand. 
experimental oestrous cycle. Oestrus was induced by inserting vaginal sponges containing $60 \mathrm{mg} 6 \alpha$-methyl-17acetoxyprogesterone (Upjohn Co. Kalamazoo, MI, U.S.A.). After 12 days (Day -2) the sponges were withdrawn (Ainsworth \& Wolynetz, 1982). The hysterectomized ewes received $100 \mu \mathrm{g}$ cloprostenol (Estrumate; ICI New Zealand Lid, N.Z.) at the time of the sponge removal to destroy any corpora lutea (CL) that were present. The experimental procedure was carried out on the cyclic ewes on Day 8 (Group C8) and Day 14 (Group C14), hysterectomized ewes on Day 14 (Group H14), Day 18 (Group H18) and Day 21 (Group H21), anoestrous ewes (Group A) and ovariectomized ewes (Group O).

Experimental procedure. On the day before PG infusion, 2 jugular vein catheters were inserted, one towards the head and the other towards the heart. PGF-2 $\alpha$ (triethylamine salt, Upjohn, Kalamazoo, MI, U.S.A.) was dissolved in saline $(9 \mathrm{~g} \mathrm{NaCl} / \mathrm{l})$ and infused, into the catheter directed towards the heart, at $1 \mathrm{ml}$ per min for $20 \mathrm{~min}$ at concentrations of $0,0.4,2,10 \mathrm{or} 50 \mu \mathrm{g} / \mathrm{ml}$. There was an interval of $1 \mathrm{~h}$ between the beginning of each infusion. In 3 of the Group C8 ewes 2 additional infusions of $10 \mu \mathrm{g}$ PGF $-2 \alpha / \mathrm{ml}$ were given at hourly intervals after the $50 \mu \mathrm{g} / \mathrm{min}$ infusion and $14 \mathrm{~h}$ later an additional infusion of $10 \mu \mathrm{g} \mathrm{PGF}-2 \alpha / \mathrm{ml}$ was given. PGFM (Upjohn Co.), was dissolved in saline $(9 \mathrm{~g}$ $\mathrm{NaCl} / \mathrm{l}$ ) and infused into 5 ewes (Group C8) at $1 \mathrm{ml} / \mathrm{min}$ for $20 \mathrm{~min}$ at $0,0.4$ and $2.0 \mu \mathrm{g} / \mathrm{ml}: 1 \mathrm{~h}$ was left between each infusion and the $2.0 \mu \mathrm{g} / \mathrm{ml}$ infusion was followed $1 \mathrm{~h}$ later by a 20 -min infusion of PGF- $2 \alpha$ at $2.0 \mu \mathrm{g} / \mathrm{ml}$. During the PG infusions, 7-ml blood samples from the jugular catheter directed towards the head were collected into ice-cold tubes containing EDTA. Samples were collected at 0, 10, 20,30 and $60 \mathrm{~min}$ from the start of each PGF-2 $\alpha$ infusion. The blood was centrifuged within $10 \mathrm{~min}$ and the plasma was stored at $-20^{\circ} \mathrm{C}$ until assayed.

Before infusion, the PGFM was purified by reverse-phase HPLC (Waters Associates) on a C18 column. The PGFM was eluted with $36 \%$ acetonitrile and $0 \cdot 1 \% \mathrm{H}_{3} \mathrm{PO}_{4}$ after 23 min which compares with the elution of tritiated PGF-2 $\alpha$ after 14 min.

Radioimmunoassays. Oxytocin-neurophysin, progesterone and PGFM were measured as described previously (Fairclough \& Payne, 1975; Moore \& Watkins, 1983; Moore et al., 1986). The oxytocin-neurophysin radioimmunoassay (RIA) recognizes equally ovine neurophysin II and its putative metabolite, ovine neurophysin I (Moore \& Watkins, 1981), and has a cross-reactivity of $2.5 \%$ with the ovine vasopressin neurophysin, neurophysin-III. The RIA has a sensitivity of $0.2 \mathrm{ng} / \mathrm{ml}$ and inter- and intra-assay variations of $5.3 \%$ and $5.7 \%$ for a sample containing labelled $1.08 \mathrm{ng}$ oxytocin neurophysin $/ \mathrm{ml}$. Progesterone was measured using a ${ }^{125} \mathrm{I}$-labelled progesterone RIA (RSL, Carson, CA, U.S.A.) with the exception that plasma from an ovariectomized sheep was added to the reference standards. All samples were measured in one assay in which an intra-assay variation of $4.5 \%$ was measured for a sample containing $4.3 \mathrm{ng}$ progesterone $/ \mathrm{ml}$. The assay had a sensitivity of $0.5 \mathrm{ng} / \mathrm{ml}$. The PGFM antiserum cross-reacted $20 \%, 0.5 \%$ and $50 \%$ with 15-keto-PGF-2 $\alpha, 13,14$-dihydro-PGF- $\alpha \alpha$ and with the 13,14-dihydro-15-keto-PGF-1 $\alpha$ derivative respectively. Since the PGFM antiserum cross-reacted $50 \%$ with the PGFM 13,14-dihydro-15-keto derivative, the results are presented as PGFM equivalents.

Statistical analysis. After subtracting the mean basal level, obtained after infusion of saline, from each observation, the non-paired $t$-test was used to determine whether the mean of these values for each of the sampling times was significantly different from zero.

\section{Results}

On Day 8 of the cycle $20 \mathrm{~min}$ intravenous infusion of PGF- $2 \alpha$ at $0.4 \mu \mathrm{g} / \mathrm{min}$ caused a small increase in oxytocin-neurophysin in 4 of the 5 ewes (Figs $1 \& 2$ ). Infusion of PGF-2 $\alpha$ at $2.0 \mu \mathrm{g} / \mathrm{min}$ caused an oxytocin-neurophysin increase in all 5 ewes with an increase of $213 \%(P<0.05)$. However, on Day 14 of the cycle (Fig. 1) increases in oxytocin-neurophysin were only observed when the infusion rates were $10 \mu \mathrm{g} / \mathrm{min}$ and $50 \mu \mathrm{g} / \mathrm{min}$ which caused increases $39 \%(P<0.05)$ and $30 \%$ $(P<0.05)$ respectively. Elimination of luteolysis inducing secretion of uterine PGF-2 $\alpha$ by hysterectomy increased the sensitivity and the degree of the response to exogenous PGF-2 $\alpha$ (Fig. 1 ). All 5 hysterectomized ewes on Day 14 of the cycle responded to the infusion of 2 and $10 \mu \mathrm{g} P G F-2 \alpha / \mathrm{min}$ with a mean $29 \%(P<0.05)$ and $141 \%$ increase $(P<0.05)$ in oxytocin-neurophysin respectively.

Fig. 1. Effect on plasma oxytocin-neurophysin concentrations of 20 -min intravenous infusions at $0,0 \cdot 4,2,10$ and $50 \mu \mathrm{g}$ PGF- $2 \alpha / \mathrm{min}$ given at hourly intervals to 5 ewes on Day 8 (Group C8) of the oestrous cycle, 5 ewes on Day 14 (Group C14), 5 hysterectomized ewes on Day 14 (Group H14), 2 hysterectomized ewes on Days 18 (Group H18) and 21 (Group H21), 5 anoestrous ewes (Group A) and 5 ovariectomized ewes (Group O). Values are mean \pm s.e.m. Mean plasma progesterone concentrations before PG infusion were $3.1 \mathrm{ng} / \mathrm{ml}$ in Group C8, $3.9 \mathrm{ng} / \mathrm{ml}$ in Group Cl4; $4.5 \mathrm{ng} / \mathrm{ml}$ in Group H14, 3.3 ng/ml in Group H18, $7.9 \mathrm{ng} / \mathrm{ml}$ in Group $\mathrm{H} 21,<0.5 \mathrm{ng} / \mathrm{ml}$ in Group A and $<0.5 \mathrm{ng} / \mathrm{ml}$ in Group O. 


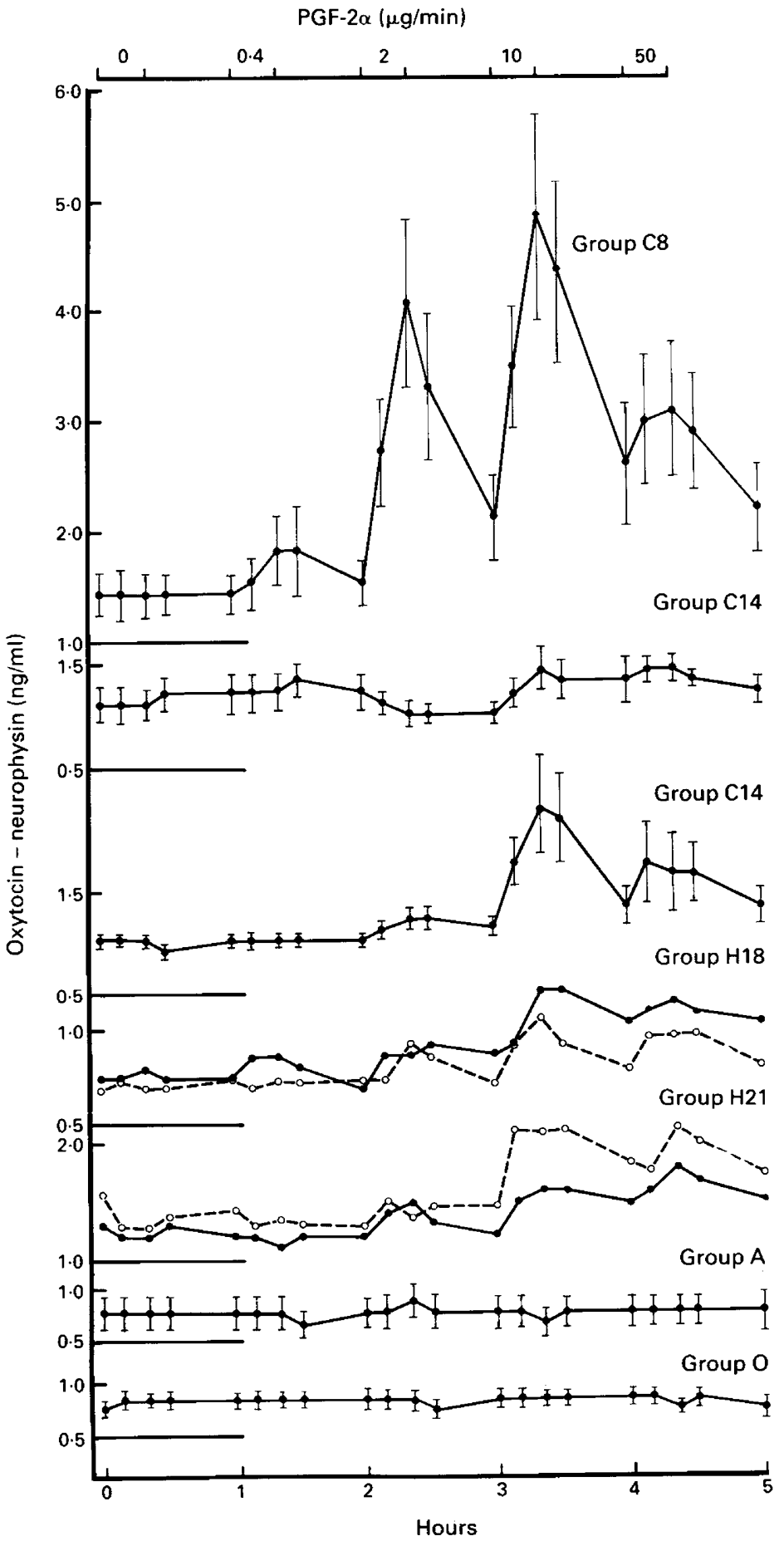




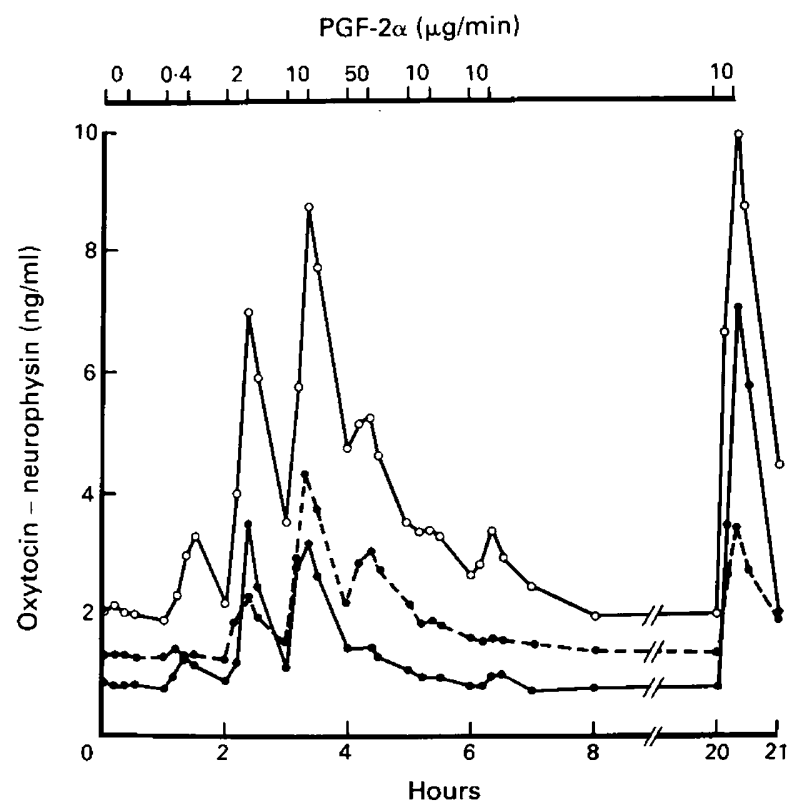

Fig. 2. Effect on plasma oxytocin-neurophysin concentrations of repeated intravenous infusions of $0,0.4,2,10,50,10$ and $10 \mu \mathrm{g}$ PGF-2 $\alpha / \mathrm{min}$ given at hourly intervals and an additional $10 \mu \mathrm{g}$ PGF- $2 \alpha 14 \mathrm{~h}$ later in 3 ewes on Day 8 of the oestrous cycle. Mean progesterone value before infusion was $30 \mathrm{ng} / \mathrm{ml}$.

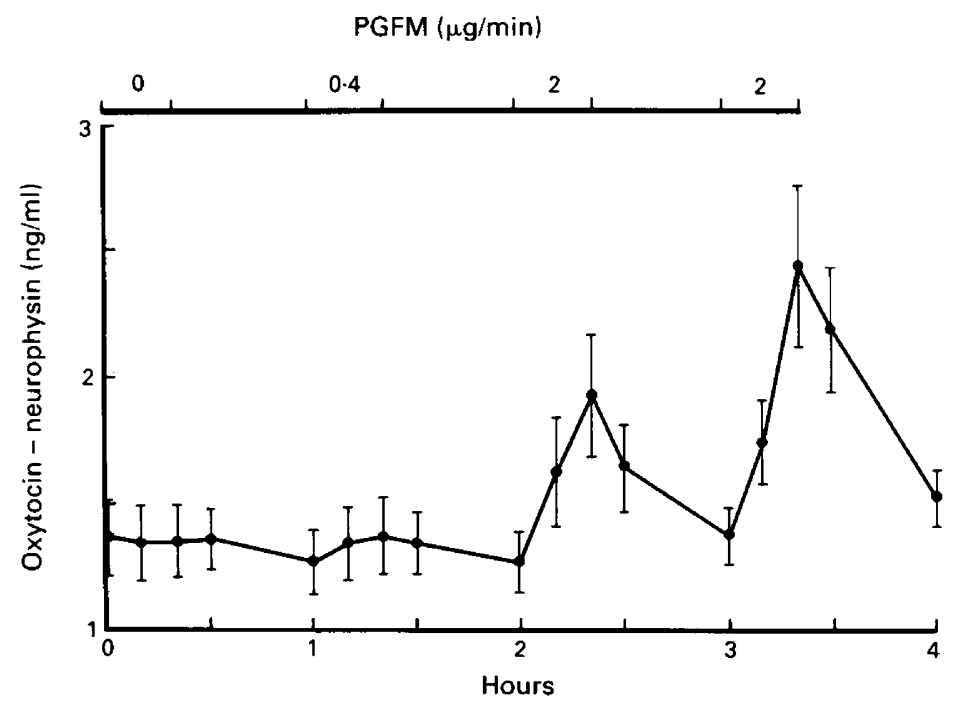

Fig. 3. Effect on plasma oxytocin-neurophysin concentrations of 20-min intravenous infusions of $0,0.4$ and $2 \mu \mathrm{g}$ PGFM/min at hourly intervals. This was followed by the infusion of $2 \mu \mathrm{g}$ PGF $-2 \alpha / \mathrm{min}$ for $20 \mathrm{~min}$ to 5 ewes on Day 8 of the oestrous cycle. Values are mean \pm s.e.m. Mean progesterone concentrations before infusion were $6.2 \mathrm{ng} / \mathrm{ml}$. 
The responses in 2 hysterectomized ewes on Day 18 and 2 on Day 21 were similar to those of Day 14 hysterectomized ewes (Fig. 1). Oxytocin-neurophysin concentrations in ovariectomized and anoestrous ewes were not affected by PGF- $2 \alpha$ infusion (Fig. 1). Repeated PGF- $2 \alpha$ infusions on Day 8 ewes (Fig. 2) demonstrated a desensitizing of the response to PGF-2 $\alpha$. However, a large increase in oxytocin-neurophysin occurred when the ewes were left for $14 \mathrm{~h}$ before PGF- $2 \alpha$ was reinfused (Fig. 2).

Infusion of PGFM at $2 \mu \mathrm{g} / \mathrm{min}$ stimulated an increase in oxytocin-neurophysin in all 5 Day8 -ewes. The $42 \%$ mean percentage increase $(P<0.05)$ was less than the $83 \%(P<0.05)$ increase stimulated by $2 \mu \mathrm{g}$ PGF- $2 \alpha / \mathrm{min}$ when it was given after the PGFM infusion (Fig. 3 ) or the $213 \%$ increase stimulated by PGF- $2 \alpha$ infusion at $2 \mu \mathrm{g} / \mathrm{min}$ into a different group of Day-8 ewes (Fig. 1).

Intravenous infusion of PGF- $2 \alpha$ for $20 \mathrm{~min}$ into 5 Day-8 ewes at $0 \cdot 4,2 \cdot 0,10$ and $30 \mu \mathrm{g} / \mathrm{min}$ caused the jugular plasma concentrations of PGFM to increase from basal levels of $0.27 \pm$ $0.17 \mathrm{ng} / \mathrm{ml}$ to $0.45 \pm 0.13,0.85 \pm 0.50,2.56 \pm 1.44$ and $11.4 \pm 5.06 \mathrm{ng} / \mathrm{ml}$ respectively. Similarly, PGFM infusion at 0.4 and $2.0 \mu \mathrm{g} / \mathrm{min}$ for $20 \mathrm{~min}$ increased basal PGFM values of $0.29 \mu \mathrm{g} /$ $\mathrm{ml} \pm 0.06,0.59 \pm 0.21$ and $0.91 \pm 0.21 \mathrm{ng} / \mathrm{ml}$ respectively.

\section{Discussion}

These results show that systemic intravenous infusion of PGF-2 $\alpha$ is able to stimulate the release of oxytocin-neurophysin. The oxytocin-neurophysin probably orginates from the CL because the Day-8 ewes which had the highest levels of CL oxytocin-neurophysin and oxytocin (W. B. Watkins, L. G. Moore, V. J. Choy \& R. J. Fairclough, unpublished) showed the greatest response to PGF-2 $\alpha$, and animals without CL (anoestrous and ovariectomized ewes) had no response to PGF-2 $\alpha$ infusion. This proposition is supported by studies on ewes on Day 11 of the cycle in which cloprostenol was shown to cause secretion of oxytocin and oxytocin-neurophysin from the ovary but not from the posterior pituitary (Flint \& Sheldrick, 1982; Watkins et al., 1984). However, in pigs (Ellendorff et al., 1979), rats (Singh \& Katzarski, 1975; Fujimoto et al., 1978; Akaishi \& Negoro, 1979) and men (Gillespie et al., 1972; Ogawa, 1979) PGF-2 $\alpha$ can cause the secretion of oxytocin from sites presumed to be the posterior pituitary. In the ewe and cow PG-stimulated secretion from non-ovarian sources has not been demonstrated (Barowicz, 1981; Flint \& Sheldrick, 1982; Schams \& Karg, 1982; Watkins et al., 1984; Schallenberger et al., 1984).

Since we have found that cloprostenol (a PGF-2 $\alpha$ analogue) (Watkins et al., 1984) and endogenous pulses of PGF-2 $\alpha$ (Moore et al., 1984) stimulate and release of equimolar amounts of oxytocin and oxytocin-neurophysin, it is likely that the observed increases in oxytocin-neurophysin are representative of similar changes in oxytocin. The rates of PGF-2 $\alpha$ and PGFM infusion which induced increases in oxytocin-neurophysin produced plasma concentrations of PGFM which are similar to the peak values of $1-3 \mathrm{ng} / \mathrm{ml}$ found during luteolysis (Fairclough et al., 1980). In cows, systemic intravenous infusion of a small quantity of PGF-2 $\alpha(1-5 \mu \mathrm{g})$ is able to cause milk ejection which is presumably due to oxytocin release (Dhondt et al., 1977). We have observed that the release of oxytocin-neurophysin and oxytocin which follows the pulsatile release of PGF-2 $\alpha$ during luteolysis originates from the ovary (Moore et al., 1984). Consequently, the oxytocin-secreting cells in the CL are likely to be exposed to a greater concentration of PGF than the peripheral levels because of the countercurrent transfer of PGF-2 $\alpha$ and possibly also PGF metabolites (Lewis et al., 1977) from the uterine vein in the ovarian artery (McCracken et al., 1972; Pexton et al., 1975). There is also evidence that PGF- $2 \alpha$ can reach the CL from the uterus by the lymphatic system (Heap et al., 1985; Abdel Rahim et al., 1984a, b). These results suggest that the release of uterine PGF- $2 \alpha$ is of sufficient magnitude to stimulate ovarian oxytocin release.

Because PGF- $2 \alpha$ is almost completely metabolized by one passage through the lungs (Piper $e t$ al., 1970; Davis et al., 1980), it is likely that it is a PGF-2a metabolite(s) that is causing the release of oxytocin-neurophysin when systemic intravenous infusions of physiological quantities of PGF-2 $\alpha$ 
are administered. When PGFM was infused into ewes it caused the stimulation of oxytocinneurophysin release. However, this release was smaller than that which followed the infusion of PGF-2 $\alpha$, which suggests that PGFM is not the only active PG capable of causing oxytocinneurophysin release from the CL. PGF-2 $\alpha$ is converted to PGFM via the intermediate 15-ketoPGF-2 $\alpha$ (Hillier, 1978). This derivative has been shown to be luteolytic in rhesus monkeys (Wilks, 1977). PGFM has no effect on luteolysis in rabbits (Kehl \& Carlson, 1981) or on smooth muscle preparations in vitro (Hoult \& Moore, 1977). However, it does have a small effect on smooth muscle in vivo (Bygdeman et al., 1974) and it is capable of binding to PGF-2 $\alpha$ receptors on the sheep CL (Powell et al., 1974). PGFM can be further reduced to 13,14-dihydro-PGF-2 $\alpha$ (Aizawa et al., 1980) which is luteolytic in cows (Milvae \& Hansel, 1983) and rabbits (Kehl \& Carlson, 1981). The affinity of PGFM for the PGF- $2 \alpha$ receptor of the sheep CL is similar to that of PGF-2 $\alpha$ (Powell et al., 1974). Administration of PGF-2 $\alpha$ to women (Gillespie et al., 1972) and 15(5),15methyl-PG-E-2 to ewes (Sheldrick \& Flint, 1984) can increase plasma concentrations of oxytocin. Further studies are needed to identify the prostaglandins which are capable of causing release of oxytocin and oxytocin-neurophysin from the CL.

Repeated infusions of PGF- $2 \alpha$ to the Day- 8 cyclic ewes caused desensitization to further PGF-2 $\alpha$. Desensitization probably explains why the PGF- $2 \alpha$ infusion had little effect on the oxytocin-neurophysin levels of Day-14 cyclic ewes yet it stimulated oxytocin-neurophysin release from Day-14 ewes which had their endogenous releases of uterine PGF- $2 \alpha$ prevented by hysterectomy. Eiler et al. (1981) found that repeated doses of PGF-2 $\alpha$ attenuated the milk ejection response to PGF-2 $\alpha$ but not to oxytocin, which suggests a desensitization in the ability of PGF-2 $\alpha$ to cause oxytocin release. This desensitization may be due to depletion of CL oxytocin because Flint \& Sheldrick (1983) found that, after the administration of $125 \mu \mathrm{g}$ cloprostenol, the CL contained only $2 \%$ of the oxytocin that it had before stimulation. This desensitization in the oxytocinneurophysin response to PGF-2 $\alpha$ may be involved in the co-ordination of the endogenous pulsatile PGF- $2 \alpha$ oxytocin releases during luteolysis. In this study, hysterectomized ewes 18 and 21 days after oestrus still released oxytocin-neurophysin in response to PGF- $2 \alpha$ infusion, although the responses tended to be less than those that occurred on Day 14. Watkins et al. (1984) did not observe any increase in secretion of ovarian oxytocin or oxytocin-neurophysin when a hysterectomized ewe (Day 53 after oestrus) was injected with cloprostenol. This decrease in response is probably due to decreased levels of CL oxytocin. Sheldrick \& Flint (1984) found that, by Day 21 after oestrus, the CL from hysterecomized ewes contained only $13 \%$ of the oxytocin concentration found during the luteal phase.

In summary, these results show that systemic infusion of PGF-2 $\alpha$ and PGFM can cause oxytocin-neurophysin release in ewes possessing a CL and suggest that pulsatile release of oxytocin and oxytocin -neurophysin observed during luteolysis could be stimulated by PGF originating from the uterus.

We thank Mr Richard Elliot and Dr German Campos for assistance with the animals and the Medical Research Council of New Zealand for financial assistance.

\section{References}

Abdel Rahim, S.E.A., Bland, K.P. \& Poyser, N.L. (1984a) Surgical separation of the uterus and ovaries with simultaneous cannulation of the uterine vein extends luteal function in sheep. $J$. Reprod Fert. 72, 231-235.

Abdel Rahim, S.E.A., Bland, K.P. \& Poyser, N.L. (1984b) Sequential changes in the concentration of prostaglandins and steroids in uterine lymph in sheep during the oestrous cycle. Prostaglandins Leukotrienes Med. 14, 403-409.
Ainsworth, L. \& Wolynetz, M.S. (1982) Synchronization of estrus and reproductive performance of ewes treated with synthetic progestogens administered by subcutaneous ear implant or by intravaginal sponge pessary. J. Anim. Sci. 54, 1120-1127.

Aizawa, Y., Inazu, N. \& Kogo, H. (1980) Catabolism of prostaglandin F-2 $\alpha$ in rat ovary: differences between ovarian and uterine tissues. Prostaglandins 20, 95-103. 
Akaishi, T. \& Negoro, H. (1979) Differential effects of prostaglandin F-2 $\alpha$ on oxytocinergic and nonoxytocinergic neurons in the paraventricular nucleus of the lactating rat. Endocrinol. jap. 26, 725-730.

Barowicz, T. (1981) The effect of prostaglandin F.2 $\alpha$ on oxytocin-induced intramammary pressure in lactating ewes. Acta physiol. pol. 32, 121-125.

Bygdeman, M., Green, K., Toppozada, M., Wiqvist, N. \& Bergstrom, S. (1974) The influence of prostaglandin metabolites on the uterine response to PGF-2a. A clinical and pharmacokinetic study. Life Sci. 14, $521-531$.

Davis, A.J., Fleet, I.R., Harrison, F.A. \& Maule Walker, F.M. (1980) Pulmonary metabolism of prostaglandin $\mathrm{F}-2 \alpha$ in the conscious non-pregnant ewe and sow. $J$. Physiol., Lond 301, 86P, Abstr.

Dhondt, G.A., Peeter, H.G. \& Jochle, W. (1977) Effect of prostaglandins F-2 $\alpha$ and E-2 on milk ejection blood pressure and mammary artery blood flow in the cow. Arch. Int. Pharmacodyn. Ther. 227, 159-161.

Eiler, H., Oden, J., Schaub, R. \& Sims, M. (1981) Refractoriness of both uterus and mammary gland of the cow to prostaglandin F2 administration: clinical implication. Am. J. vet. Res. 42, 314-317.

Ellendorff, F., Forsling, M.L., Parvizi, N., Williams, H., Taverne, M. \& Smidt, D. (1979) Plasma oxytocin and vasopressin concentrations in response to prostaglandin injection into the pig. $J$. Reprod. Fert. 56, 573-577.

Fairclough, R.J. \& Payne, E. (1975) Radioimmunoassay of 13,14-dihydro-15-keto prostaglandin $\mathrm{F}$ in bovine peripheral plasma. Prostaglandins 10, 266-272.

Fairclough, R.J., Moore, L.G., McGowan, L.T., Peterson, A.J., Smith, J.F., Tervit, H.R. \& Watkins, W.B. (1980) Temporal relationship between plasma concentrations of 13,14-dihydro-15-keto-prostaglandin $F$ and neurophysin I/II around luteolysis in sheep. Prostaglandins 20, 199-208.

Flint, A.P.F. \& Sheldrick, E.L. (1982) Ovarian secretion of oxytocin is stimulated by prostaglandin. Nature, Lond. 297, 587-588.

Flint, A.P.F. \& Sheldrick, E.L. (1983) Evidence for a systemic role for ovarian oxytocin in luteal regression in sheep. J. Reprod. Fert. 67, 215-225.

Fujimoto, S., Hisada, S. \& Tsushima, H. (1978) The oxytocic effect of centrally injected prostaglandins E2 and F2a. Jap. J. Pharmac. 28, 791-793.

Gillespie, A., Brummer, H.C. \& Chard, T. (1972) Oxytocin release by infused prostaglandin. Br. med. J. 1, 543-544.

Heap, R.B., Fleet, I.R. \& Hamon, M. (1985) Prostaglandin $F-2 \alpha$ is transferred from the uterus to the ovary in the sheep by lymphatic and blood vascular pathways. $J$. Reprod. Fert. 74, 645-656.

Hillier, K. (1978) Prostaglandins and thromboxanes: pharmacologic and biosynthetic aspects. Semin. Perinatol. 2, 197-210.

Hoult, J.R.S. \& Moore, P.K. (1977) Pathways of prostaglandin F-2 metabolism in mammalian kidneys. Br. J. Pharmacol. 61, 615-626.

Kehl, S.J. \& Carlson, J.C. (1981) Assessment of the luteolytic potency of various prostaglandins in the pseudopregnant rabbit. J. Reprod. Fert. 62, 117-122.

Lewis, G.S., Wilson, L., Wilks, J.W., Pexton, J.E.,
Fogwell, R.L., Ford, S.P., Butcher, R.L., Thayne, M.V. \& Inskeep, E.K. (1977) PGF-2 $\alpha$ and its metabolites in uterine and jugular venous plasma and endometrium of ewes during early pregnancy. J. Anim. Sci. 45, 320-327.

McCracken, J.A., Carlson, J.C., Glew, M.E., Goding, J.R., Baird, D.T., Green, K. \& Samuelsson, B. (1972) Prostaglandin F2 $\alpha$ identified as a luteolytic hormone in sheep. Nature (New Biol.) 238, 129-134.

Milvae, R.A. \& Hansel, W. (1983) Luteolytic effect of 13, 14-dihydro-PGF-2 $\alpha$ in heifers. J. Reprod. Fert. 67, 203-207.

Moore, L.G. \& Watkins, W.B. (1981) Purification of sheep neurophysins from whole pituitary glands and proposed relationships between neurophysins-I and -II and the neurohypophysial hormones. Neuropeptides 2, 75-88.

Moore, L.G. \& Watkins, W.B. (1983) Development of radioimmunoassays for ovine neurophysins. Correlation of neurophysin release with oxytocin- and vasopressin-related stimuli. Endocrinology 112, $113-120$.

Moore, L.G., Watkins, W.B., Choy, V.J. \& Elliot, R.L. (1984) Release of oxytocin, neurophysin and prostaglandin $F-2 \alpha$ into the utero-ovarian vein during luteolysis. Proc. Endocr. Soc. Australia 27, 59, Abstr.

Moore, L.G., Watkins, W.B., Choy, V.J. \& Elliot, R.L. (1986) Evidence for the pulsatile release of prostaglandin F-2 $\alpha$ inducing the release of ovarian oxytocin during luteolysis in the ewe. J. Reprod. Fert. 76, 159-166.

Ogawa, S. (1979) Change of plasma oxytocin level during administration of prostaglandin $F-2 \alpha$ in normal male. Horiae 27, 1269-1271.

Pexton, J.E., Weems, C.W. \& Inskeep, E.K. (1975) Prostaglandins $F$ in uterine and ovarian venous plasma from nonpregnant and pregnant ewes collected by cannulation. Prostaglandins 9, 501-509.

Piper, P.J., Vane, J.R. \& Wyllie, J.H. (1970) Inactivation of prostaglandins by the lungs. Nature, Lond. 225, 600-604.

Powell, W.S., Hammarstrom, S. \& Samuelsson, B. (1974) Prostaglandin F-2 $\alpha$ receptor in ovine corpora lutea. Eur. J. Biochem. 41, 103-107.

Roberts, J.S., Barcikowski, B., Wilson, L., Skarnes, R.C. \& McCracken, J.A. (1975) Hormonal and related factors affecting the release of prostaglandin $F-2 \alpha$ from the uterus. J. Steroid Biochem. 6, 1091-1097.

Schallenberger, E., Schams, D., Bullermann, B. \& Walters, D.L. (1984) Pulsatile secretion of gonadotrophins, ovarian steroids and ovarian oxytocin during prostaglandin-induced regression of the corpus luteum in the cow. $J$. Reprod. Fert. 71, 493-501.

Schams, D. \& Karg, H. (1982) Hormonal responses following treatment with different prostaglandin analogues for estrous cycle regulation in cattle. Theriogenology 17, 499-513.

Schams, D., Prokopp, S. \& Barth, D. (1982) The effect of active and passive immunization against oxytocin on ovarian cyclicity in ewes. Acta endocr., Copenh. 103, $337-344$.

Sheldrick, E.L. \& Flint, A.P.F. (1984) Ovarian oxytocin and luteal function in the early pregnant sheep. Anim. Reprod. Sci. 7, 101-113. 
Sheldrick, E.L., Mitchell, M.D. \& Flint, A.P.F. (1980) Delayed luteal regression in ewes immunized against oxytocin. J. Reprod. Fert. 59, 37-42.

Singh, U. \& Katzarski, M. (1975) Effect of prostaglandin F-2 alpha on the neurohypophysis: A historical study. Acta morph. Acad. Sci. hung. 23, 51-57.
Watkins, W.B., Moore, L.G., Flint, A.P.F. \& Sheldrick, E.L. (1984) Secretion of neurophysins by the ovary in sheep. Peptides 5, 61-64.

Wilks, J.W. (1977) Luteolytic action of 15-ketoprostaglandin F-2 $\alpha$ in the rhesus monkey. Prostaglandins 13, 161-170.

Received 28 July 1986 